The fiscal impact of EU immigration on the tax-financed welfare state: Testing the 'welfare burden' thesis

Martinsen, Dorte Sindbjerg; Rotger, Gabriel Pons

Published in:

European Union Politics

DOI:

$10.1177 / 1465116517717340$

Publication date:

2017

Document version

Peer reviewed version

Citation for published version (APA):

Martinsen, D. S., \& Rotger, G. P. (2017). The fiscal impact of EU immigration on the tax-financed welfare state:

Testing the 'welfare burden' thesis. European Union Politics, 18(4), 620-639. [6].

https://doi.org/10.1177/1465116517717340 


\title{
The fiscal impact of EU immigration on the tax-financed welfare state: testing the 'welfare burden' thesis
}

\author{
Dorte Sindbjerg Martinsen, Department of Political Science, University of \\ Copenhagen, Copenhagen, Denmark \\ Gabriel Pons Rotger, SFI, the Danish National Centre for Social Research, \\ Copenhagen, Denmark
}

Published in

\section{European Union Politics}

DOI: $\underline{10.1177 / 1465116517717340}$

\begin{abstract}
The European Union's rules on free movement of people and the right to crossborder welfare are increasingly contested and have evoked one of the most salient debates in EU politics. The assumption that EU immigrants pose a net "welfare burden' on the host member state has sounded loud and wide in recent years. This calls for an empirical test. In this article, we examine the fiscal impact of EU immigration on the universalistic, tax-financed welfare state of Denmark. We analyse EU citizens' contribution to and consumption of welfare benefits between 2002 and 2013 on the basis of a unique dataset of administrative data, consisting of repeated cross sections of $100 \%$ of the EU population residing in Denmark. We find that EU immigrants made a significant positive net contribution to the Danish welfare state over the long time span examined and thus reject the 'welfare burden' thesis for the crucial case of Denmark.
\end{abstract}

Key words: European Union, fiscal impact, free movement of people, 'welfare burden' thesis, welfare state 


\section{Introduction}

The European Union (EU) has long embarked on a 'radical experiment' with open, internal borders for its citizens and conditioned access to cross-border welfare for those on the move (Geddes and Hadj-Abdou, 2016: 222). Across the globe, states tend to carefully guard their borders, residence rights and access to their welfare schemes. A trade-off between countries' openness to admitting immigrants and the rights granted to immigrants after admission has been identified (Ruhs, 2013). The international trend is that openness comes with a price in the sense that states with more liberal immigration policies are more restrictive regarding access to rights, including social rights (Ruhs, 2013). Here, EU rules contrast sharply. The EU has for decades moved in the opposite direction and institutionalized a logic of opening. In particular, EU citizens' entitlement to become members of the welfare community of another member state is rather exceptional, as welfare states otherwise rely on a profound logic of closure (Ferrera, 2005; Heindlmaier and Blauberger, 2017; Martinsen and Vollaard, 2014;).

The viability of this exceptionalism is questioned, however, and its implications for the welfare state discussed. Political concerns of welfare states' sustainability in a community where Union citizens can move and reside freely have been loudly expressed (Hemerijck, 2013; Heindlmaier and Blauberger, 2017; Hjorth, 2016; Kvist, 2004. Concerns that EU immigrants 'take out' more than they 'put in' are increasingly voiced (Dustmann et al., 2010: 2; Dustmann and Frattini, 2014: 628; Ruist, 2014). In particular, such concerns were voiced in relation to the grand EU enlargement of 2004, where eight Central and Eastern European states ${ }^{1}$ became members (Dustmann et al., 2010: 2; Ruist, 2014: 21). Together, the enlargements of 2004 and 2007 implied an enormous increase in the institutional, economic and social heterogeneity of the Union (Hemerijck, 2013: 290; Höpner and Schäfer, 2012: 436-437), leading to a resurgence of nationalist and welfare chauvinist sentiments in the old member states (Hemerijck, 2013: 320; Hjorth, 2016).

Governing politicians have also sounded their concerns with increasing volume. In April 2013, the ministers of the interior from Germany, Austria, the Netherlands and the UK sent a joint letter to the Council of the European Union stating the view that 
free movement of persons and access to welfare should not be unconditional. Together with Denmark, these member states have since 2013 pushed for the European Commission to propose more restrictive rules on access to EU cross-border welfare. In particular, concerns about more immediate access to welfare have been expressed, where EU immigrants after a short period of residence and/or work would be granted benefits before having earned their way into the system. The politicization of the free movement and welfare state nexus recently came to an extreme with the UK referendum on EU membership. Free movement of persons and 'welfare tourism' were main themes in the political debate and according to Reenan among the most important reasons for the UK exit decision (Reenen, 2016). In sum, constitutive EU principles are increasingly contested, and with the results of the UK referendum, the very fundament of the Union itself is indeed shattered. More member states may follow the UK exit path (Reenen, 2016).

Thus, the assumption that immigration of EU citizens from other member states poses a net burden on the welfare state is widely stated. The assumption has considerable political implications, as it brings constitutive EU principles into question and regards them as unsustainable. Despite its wide and growing political implications for the European Union, few scholars ${ }^{2}$ have addressed this "welfare burden' thesis empirically. In this article, we investigate the fiscal impact of EU immigration on the Danish welfare state over a long time span to put the "welfare burden' thesis to empirical test. Our purpose is to examine the extent to which EU immigrants 'pay their way in the welfare system' (Dustmann et al., 2010: 2) or affect public revenues negatively. We argue that the Danish universalistic, tax-based welfare state is a crucial case for examining whether EU immigrants are net burdens on the welfare state of a hosting country. In this welfare state type, the link between contributions and entitlements is only indirect. Tax-financed welfare benefits can be accessed without having paid social security contributions or without being a longterm member of the welfare community. Denmark is a rather pure example of this welfare state type, with the largest share of non-contributory benefits among its EU counterparts. $^{3}$ 
Our analysis on fiscal impact is carried out on the basis of a unique dataset of individual Danish register data. We have gained access to a host of public administrative register data, i.e. individual data, for the full EU population's use of welfare benefits and services and their contributions to the public revenues, primarily by means of tax-payment in 2002-2013. Danish register data are directly reported from the Danish tax agency and the municipalities to the Danish national statistical office 'Statistics Denmark'. The fact that data are reported directly by the public authorities, instead of by individuals themselves, to the national statistical office makes them highly reliable. Denmark is the only country where researchers can merge information across sectors and have detailed information about benefits received and contributions made on a weekly and monthly basis. The level of information is remarkable and unique. Thus, for each year, we have computed contributions and expenditures from $100 \%$ of the population of EU citizens residing in Denmark and estimated the net fiscal impact for the EU population as a whole and subdivided into different groups.

Our analysis extends substantially beyond existing studies of EU immigrants' fiscal impact because it provides a comprehensive examination of the full EU population over a long time span. Furthermore, it should be noted that the 2002-2013 time span involves important structural changes for the European Union that test the welfare sustainability of EU rules: three enlargements with a considerable increase in the Union's socio-economic heterogeneity, financial and economic crises and important changes in EU rules and rights concerning EU migrants. Like most other EU member states, Denmark had a transition agreement after the 2004 and 2007 enlargements according to which immigration from the new East European member states required a work permit. The Danish transition agreement ran from 1 May 2004 to 1 May 2009. Thus, our time span examines fiscal impact more than four years after the end of the transition agreement.

Below, we present the EU free movement rules and the right to cross-border welfare and argue why they can be regarded as rather exceptional rules, although the rights of EU citizens to equal treatment in terms of welfare are still conditioned. We then present the characteristics of the Danish universalistic, tax-based welfare state as 
unique in its own right, making it more likely to confirm the 'welfare burden' thesis. The data of our study are subsequently presented, followed by analysis of the fiscal impact of EU immigration on the universalistic welfare state of Denmark. We examine the evolution of EU immigration to Denmark, its fiscal impact in aggregate and on average and by different components, namely, age, years since migration and country of origin. We conclude by rejecting the 'welfare burden' thesis on the basis of our findings. Even in a period of considerable structural change, EU immigrants made a significant positive net contribution to the Danish welfare state.

\section{European Union exceptionalism: free movement and cross-border welfare}

Compared to other advanced economies, the European Union's free movement principle for persons is exceptional indeed (Ruhs, 2015). Since the adoption of the Treaty of Rome in 1957, free movement of workers has been a constitutive principle of the European Community (see article 48 of the EEC Treaty (now article 45 TFEU)). The right to move and reside freely in the Union has subsequently been extended to all EU citizens, meaning all persons holding citizenship of one of the member states and their family members. This implies that member states in general cannot deny residence rights to citizens from their fellow member states. Such exceptionalism is even more remarkable given that the free movement right applies to all, disregarding qualifications or education of the migrant worker. Whereas there is a clear international tendency for countries to design their immigration policies to attract the highly skilled and well educated (Chaloff and Lemaitre, 2009), this is not possible according to the EU rules. All EU workers enjoy the right to reside in another member state. Furthermore, EU free movement rights also apply to economically inactive citizens, as long as they do not constitute an 'unreasonable burden' on the social assistance system of the host member state (see article 14 (1) of Directive 2004/38/EC).

The unique character of EU free movement is even more evident considering that when EU citizens use their right to free movement, they also have access to the welfare benefits of the host state. Not only did the Treaty of Rome adopt free 
movement for workers, but it also stated that a worker moving from one member state to another has the right to access the social security schemes of other member states and to export previously earned social security rights to other member states (see article 51 of the EEC Treaty (now article 48 TFEU)).

From the outset, Community rules have contradicted the negative trade-off between openness and welfare rights (Ruhs, 2013) in favour of the idea that effective free movement depends on access to welfare across borders. Two Community regulations are meant to facilitate free movement. Regulation 883/2004 covers all EU citizens and their family members and grants access to and exportability of a wide range of social security benefits, including health care; maternity and equivalent paternity benefits; old-age benefits; unemployment benefits, and family benefits, but not social assistance. Regulation 492/2011 further consolidates the rights of migrant workers. This regulation covers workers only, but the Court of Justice of the European Union (CJEU) has developed a broad definition hereof, including workers with low income and part-time work (See the Kempf (C-139/85), Megner and Scheffel (C-444/93) and Ninni-Orasche (C-413/01) cases among other cases). In addition, the regulation ensures that worker status is maintained if one's job is lost and gives access to all 'social advantages' in a host member state, including social assistance and study grants. However, these social advantages cannot be exported. ${ }^{4}$ The family members of EU citizens and workers are also covered by the right to free movement within the Union and the right to EU cross-border welfare. In addition, the CJEU has had an important role in interpreting the scope of EU citizens' rights to the welfare benefits of a host member state and to treatment equal to that state's own nationals. Thus, in a number of cases, the Court embarked on a more expansive line of interpretation, granting Union citizens right of residence and equal treatment as well as access to the welfare schemes of a host member state, despite being economically inactive (See the Sala (C-85/96), Grzelczyk (C-184/99) and Baumbast (C-413/99) cases among other cases). In these cases, the Court developed a distinct vision of Union citizenship as a fundamental status of Member State nationals (Dougan, 2013: 133). The Court stated that if a certain link had been established between a citizen and a host member state, this could justify the right to welfare benefits. 
However, whereas the Union rules mark a fundamental intervention into the national prerogative to define the members of social communities (Cornelissen, 1996; Ferrera, 2005), it is not without limits. In 2004, the EU adopted the Residence Directive 2004/38, which further details the link between the right to reside and access to welfare benefits for the European migrant. The directive's article 24 states that the right to equal treatment is subject to the conditions laid down in the Treaty and in secondary law. The residence directive poses a number of conditions on the right to reside, of which the need for social assistance is the most important. The need for social assistance may terminate the right to residence. Whether one qualifies for equal treatment depends on one's status as a worker and/or the length of residence. The more recent judicial interpretations by the CJEU mark a further turn away from the previous distinct vision of European citizenship. The Court has embarked on a more restrictive course of legal integration, turning away from granting rights based on the Treaty's provision on European citizenship and instead paying closer attention to the words of the EU legislature, as stated in the Residence Directive (Dougan 2013: 140). In particular the case law of Dano (C-333/13), Alimanovic (C-67/14), García-Nieto (C-299/14) and European Commission $v$. United Kingdom (C-308/14) clearly depart from the earlier, expansive interpretations of the Court. These cases are, however, ruled after the period analysed in this article and thus do not affect the fiscal impact study conducted below.

In sum, European citizens are equal, but some European citizens are more equal than others. EU rules on free movement within the Union and cross-border welfare remain exceptional compared to other immigration policies, but they are not unconditional.

\section{Free movement and the universalistic welfare state}

Like the other Nordic welfare states, the Danish welfare state is often presented as distinct. It is characterized as universalist, largely de-commodified, residence-based, non-contributory and relatively generous (Cox, 2004; Esping-Andersen, 1990; Ruhs, 2015). First, the Danish welfare state has traditionally been characterized as universalist, promoting equality of status among its citizens. In the Scandinavian 
systems of universalism, the needy is not distinguished from the non-needy. Welfare universalism benefits the middle class and the poor because most benefits are available to all citizens. Social policies are not targeted to low-income groups as in the residual welfare state, and they are not dependent on labour market participation as in the insurance-based welfare state. Second, according to Esping-Andersen's famous welfare worlds, a key feature of the Nordic model is the high degree of 'decommodified' welfare rights. A de-commodified welfare state will thus grant social rights on the basis of citizenship or residence rather than on the basis of market performance, i.e. attachment to the labour market (Esping-Andersen, 1990).

Third, social rights are granted on the basis of residence (Cornelissen, 1996). A person is entitled to welfare because s/he is a citizen or a habitual resident, not qua individual contributions paid to a specific scheme. Fourth, benefits have traditionally been tax-financed. However, tax payment is not a direct requirement to receive a specific social benefit. The Scandinavian welfare state has thus traditionally had an institutionalized principle of equal treatment for the members of its welfare communities. Finally, the Scandinavian model has also been characterized by relatively generous benefits and extensive welfare services (Lindbom, 2001).

Because of these characteristics, the Danish welfare state has been viewed as 'unfit' for Union rules where EU citizens have a right to reside and access welfare across borders. Its universalistic, relatively de-commodified and generous nature should make it particularly attractive to EU immigrants. Furthermore, its residence and noncontributory character would make it vulnerable in a community of open welfare borders because the organizing logic of the system does not ensure that those who benefit also contribute (Scharpf, 2002, 2010). Basically, this type of welfare state is found to be out of tune in its current institutional set-up but also for historical reasons. When the cross-border welfare rules were originally designed, the six founding members all had insurance-based welfare systems. The community rules came to match this insurance-based logic. Welfare rights were to be granted according to where one works, i.e. according to the 'lex loci laboris' principle and where one paid into the social security scheme (Christensen and Malmstedt, 2000; Cornelissen, 1996). This would ensure a balance between contributions paid and 
benefits received. This contrasts with the residence-based and non-contributory welfare state, which compared to the other member states has been perceived as most exposed to the rationale of EU cross-border welfare and, as a distinct welfare state within an exceptional system, more vulnerable (Martinsen, 2005).

The Danish welfare state is thus a most likely or crucial case to examine core claims of the 'welfare burden' thesis (for the logic behind most likely or crucial cases and its strong ability to serve as empirical theory testing, see George and Bennett, 2005, Gerring, 2007). We identify at least three core claims that should be considered for empirical test:

1) The EU free movement and cross-border welfare rules are more likely to pose a burden on more inclusive and generous welfare states.

2) EU immigrants from the new member states are more likely to be net burdens to the host welfare state than EU immigrants from the old member states, as their wage levels will be low, and they will contribute less to the public purse.

3) EU immigrants with short-term residence are more likely to be net burdens to the host welfare state than EU immigrants with longer term residence, as they may benefit from the system before they have earned their way into it.

\section{Data}

Our research design has common features with the recent literature on EU fiscal impact assessment. We adopt a static approach over a long period of time, as Dustmann and Frattini (2014) do, to assess the evolution of fiscal contribution under different degrees of EU mobility and accessibility to Danish welfare. However, we depart from the studies of Dustmann and co-authors by estimating net fiscal impact directly on the basis of individual data (see Ruist, 2014, for similar methods). Danish administrative register data allow us to directly ascribe to each EU citizen tax contributions, income transfers and use of public services. 
The main contribution of this study is the computation of fiscal impact for $100 \%$ of the population of EU citizens in another EU country. Our dataset includes repeated cross sections of $100 \%$ of the population of EU citizens in Denmark on 31 December of each year between 2002 and 2013. We have been able to gain access to the full population of EU citizens, which is seldom granted and has to our knowledge not been compiled before in Denmark or beyond. Thus, this unique dataset enables us to describe the evolution of EU citizens' welfare consumption and contribution over a long period of time. Differently from other studies, we do not exclude EU citizens on the basis of their length of residence. ${ }^{5}$ Instead, we estimate fiscal impact for the stock of EU population in Denmark and for the subsamples of shorter term and longer term migrants. This separate analysis permits assessing eventual changes over time in the composition of inflow and outflow of EU migrants in terms of their contribution to Danish welfare. We study, in addition, the separate fiscal impact of migrants from old EU countries and new EU countries, as the migration population from Central and Eastern European countries is growing faster than that from traditional EU countries. Finally, we consider also the fiscal contribution of different age groups.

We construct a dataset for each year by merging a host of administrative registers to such populations of EU citizens. These data contain information on each person's total amount of public income transfers and total payment of personal income tax, labour market contribution and tax on real property. The dataset, in addition, contains individual information on the use of health care services, criminal charges, day-care, school, and secondary and higher education. Finally, we use population and migration administrative register information to measure socio-demographic and income information and the length of residence in Denmark.

For EU citizens residing in Denmark on 31 December 2002-2013, we examined their fiscal contribution and welfare consumption for each year. The fiscal contributions include income tax, property tax, labour market contribution and value added tax (VAT). We have compiled most contribution items directly based on administrative information at the individual level, with the exception of contribution via VAT and levies. VAT is calculated indirectly as $24.5 \%$ of EU citizens' disposable income, a highly reliable variable that we observe for the whole population. We here rely on 
the Danish authorities' standard estimation of contribution via VAT, which is used in general across age groups and nationalities. ${ }^{6}$ It may, however, be argued that EU immigrants with shorter term residence in a host country save more or send part of their income to relatives in their country of origin and therefore do not contribute as much as the national population via VAT. To take this into account, we calculated a lower percentage of VAT contribution for the first five years of residence, starting with $12.25 \%$ VAT contribution during the first year of residence and then increasing linearly to $24.5 \%$ VAT contribution after five years of residence. This means that for the first five years of residence, we estimate the remittance from VAT payment rather conservatively.

Concerning the public expenditures from EU immigrants in Denmark, we compiled data for received cash benefits and benefits in kind. For cash benefits, it is possible to extract data on the exact paid out amount by means of Danish register data. The expenditures for all accessible cash benefits were compiled at an individual level: unemployment benefits, health and parental benefits, social assistance, integration allowance, social pension, study grant, family benefits, pension benefits, early retirement benefit and housing allowance.

For welfare services, granted as benefits in kind, administrative individual data informs us of the consumption hereof, but not of the costs. As the use of welfare services is a relatively important part of expenditures in the Danish public sector, we compiled data on EU immigrants' use hereof at the individual level. The data on individual enrolment in day-care and elementary school allow us to identify individuals' use of pre-school and school services. Our dataset furthermore allows us to identify individuals enrolled in secondary education or higher education programmes. In addition, our data allow us to identify the individual use of the healthcare sector: consultation by a general practitioner or dentist and hospitalization. Finally, criminal charges against EU immigrants are also identifiable in our dataset. It should be noted that our estimate of criminality costs can be considered as an upper bound because not all charges end with convictions. We have estimated the costs of welfare services for each year between 2002 and 2013 based on different sources. The cost per unit estimates of having a child enrolled in day-care (i.e. cover 
crèche, day-care, nursery schools and age-integrated institutions) per year rely on the official estimates developed by the Ministry of Social Affairs and the Interior. The costs per unit estimates for being enrolled in elementary school per year rely on the official estimates developed by the Ministry of Social Affairs and the Interior. The cost per secondary education enrolment per year is proxied by the rate the state pays to each secondary educational institution per full-time equivalent (FTE; i.e. 'Taxametertakst'). These data are retrieved from the Ministry for Children, Education and Gender Equality. Data on the cost per unit for higher education is proxied by the rate the state pays to each higher education institution per FTE (i.e. 'Taxametertakst'). These data are available from the Ministry of Higher Education and Sciences. The yearly total public expenditures to general practitioners have been extracted from the financial statement of the Regions. The number of consultations per year is retrieved from Statistics Denmark. The cost per unit is calculated by dividing total expenditures by total number of consultations. Data on the total expenditures to dentistry and on consultations are extracted from Statistics Denmark's database. The cost per unit is calculated by dividing total expenditures by total number of consultations. Data on the total hospital expenditures and number of hospitalizations have been extracted from Statistics Denmark's public expenditures section. The cost per unit estimate is the total expenditures divided by the number of hospitalizations (for the same method, see Jacobsen et al., 2011: 23). For the unit cost of criminal charges, we base our estimates on the 2009 estimate in Jacobsen et al. (Jacobsen et al., 2011: 23). The 2009 estimate is used for the whole period under investigation. $^{7}$

Concerning public goods, the ideal would be to calculate the marginal costs for providing public goods for each arriving immigrant (see Dustmann and Frattini, 2014: 599 for their considerations on using marginal versus average cost of public goods). However, no data are available for the marginal costs of providing public goods to immigrants. We therefore calculated the average costs of public goods, i.e. the ratio of total expenditures for public goods to the total population. ${ }^{8}$ The public goods' costs cover a long list of items, including costs for legislative and administrative institutions, fiscal affairs, external affairs, defence, transport and infrastructure maintenance, fire protection, public order and safety, waste 
management, environmental protection, etc. Many of the items are 'pure' public goods in the sense that costs are fixed irrespective of the size of the population. The average costs of public goods are therefore likely to overestimate the actual costs implied by the EU immigrant. In our analysis below, we therefore generally hold the marginal cost of public goods equal to zero but add a lower bound calculation of the average fiscal impact where the marginal cost of public goods is equal to the average cost (see Figure 2c below).

For the examination of the net fiscal contribution for different populations of EU citizens in Denmark, this is obtained by the difference in means between contributions and expenditures. In this way, we can examine the extent to which EU immigrants in Denmark 'pay their way' in the welfare system (Dustmann et al., 2010: 2) over a long period of time.

Finally, it should be noted that we have not been able to take into account the contribution of EU citizens to corporate tax in Denmark, a feature that can underestimate the total contribution of EU citizens to the Danish welfare system.

\section{EU Immigration to Denmark 2002-2013}

We define an EU immigrant as an individual residing in Denmark in the observation year with citizenship from a country member of the EU on 31 December of the observation year, irrespective of the year of arrival or length of migration. In Figure 1, we report graphically the population of EU immigrants in Denmark during the years between 2002 and 2013 by different individual characteristics. In this period, the number of EU citizens in Denmark increased considerably from 53,782 to 159,857 people (see Figure 1a). Over the 12-year timespan, EU citizens residing in Denmark increased by approximately $146 \%$. However, this important increase in EU immigration to Denmark is not equally distributed across different age groups (Figure 1b). ${ }^{9}$ Notably, the group of EU immigrants aged between 25 and 44 has grown at a much faster pace than the remaining age groups, such that the age distribution of EU immigrants in Denmark is increasingly concentrated in this young worker age group, with the other age groups following similar trends. The groups of 
retired EU immigrants and children are the smallest. These are also the groups with potentially the most negative impact on the fiscal contribution of EU citizens. Figure 1c plots the evolution of the population of immigrants from old EU countries and from new EU countries. This plot clearly shows that in the future, the number of EU citizens from the new member states will outnumber the more traditional population of EU immigrants. Ultimo 2013, the five main states of origin for EU citizens in Denmark were Poland, Romania, Sweden, Germany and the UK. Finally, Figure 1d shows the evolution of temporary (under three years since migration) and more permanent EU immigrants (at least three years since migration). This plot reveals that both groups are growing at a similar pace and that the stock of temporary immigrants is more sensitive to the business cycle. To sum up, over the examined time span, we see an important increase in the number of EU immigrants in Denmark, changing the EU immigration pattern towards an immigrant population that increasingly originates in the new member states and is concentrated at a younger working age. 
(a)

EU

Citizens

in

Denmark

(b)

EU

Citizens in Denmark

By

Age

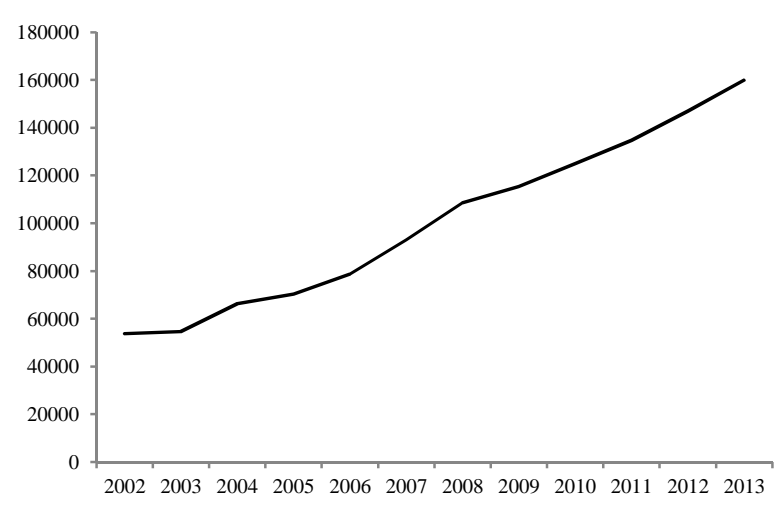

—EU CITIZENS

(c) EU Citizens in Denmark By Country of Origin

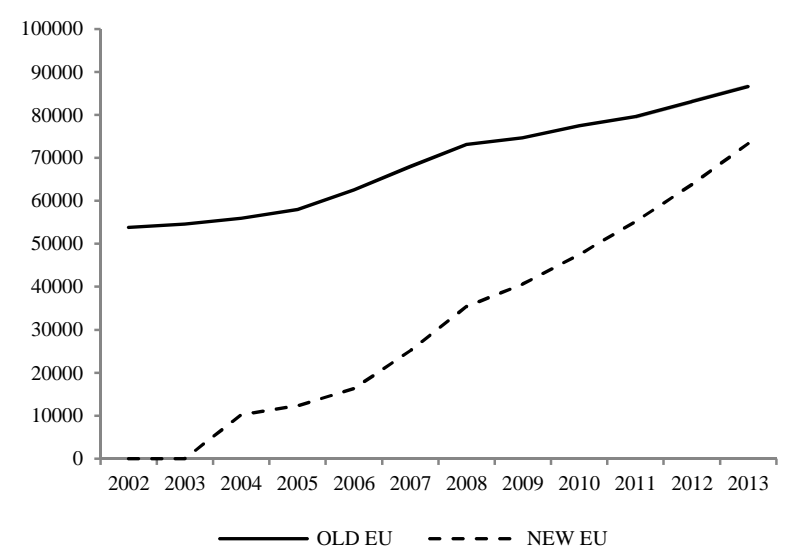

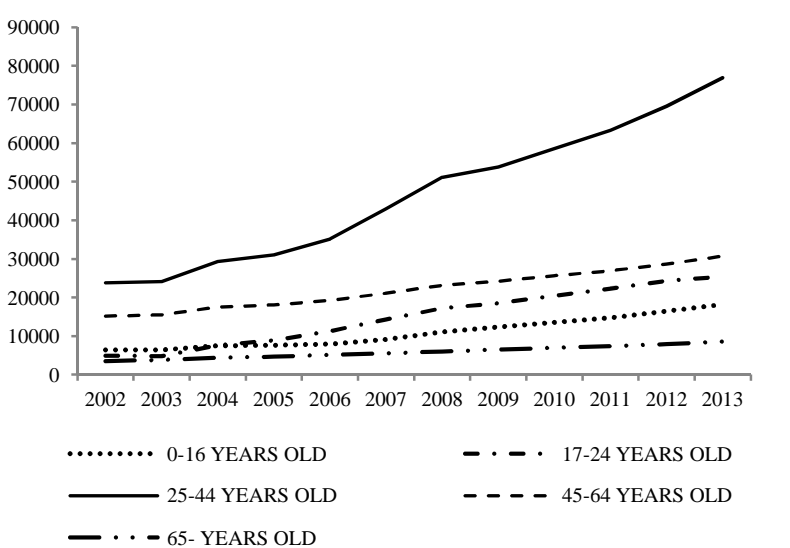

(d) EU Citizens in Denmark By Years Since Migration

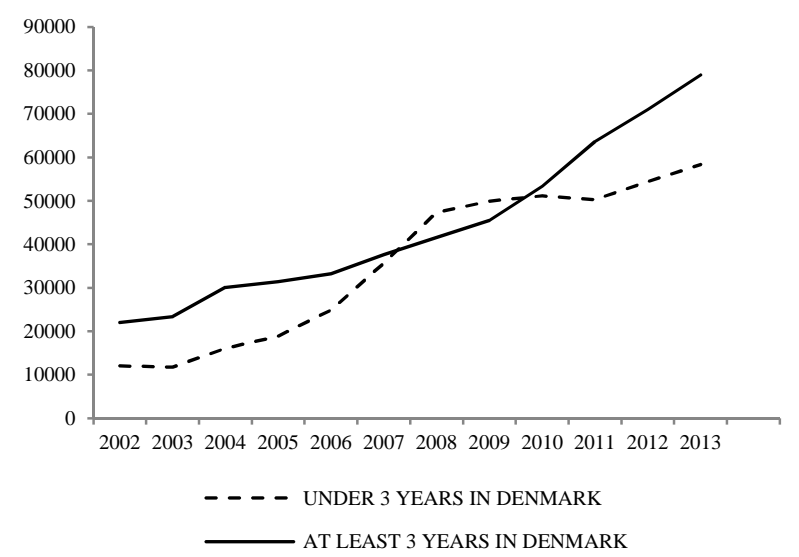

Figure 1. Population of EU Citizens in Denmark, by Individual Characteristics

Notes: (a) The number of residents in Denmark each 31 December of the current year with citizenship from a member state of the EU; (b) The number of EU citizens in Denmark by age group; (c) The number of EU citizens with citizenship of countries entering the EU before May 2004 (solid line) and the number of EU citizens from countries entering the EU after May 2004 (dashed line); (d) The number of EU citizens in Denmark for two subsamples according to their years since migration to Denmark. The solid line denotes the numbers of EU citizens who have been in Denmark for at least three years, whereas the dashed line denotes EU citizens who have been in Denmark for less than three years. Note that the descriptive evidence on the cohorts concerning years since migration are not available for $100 \%$ population of EU citizens with residence in Denmark as there are some missing observations in Danish register data.

The Online appendix presents summary statistics for the overall EU population in Denmark, by year of observation and by length of residence. The table shows that on 
average an EU citizen is approximately 35 years old and has been in Denmark for 5.5 years. However, the average age of EU citizens falls over the studied period from 38 in 2002 to 34 years old in 2013 because of the high presence of younger EU immigrants from the new member states. Despite the important increase in the number of EU immigrants and the changes in age and country of origin, many characteristics of EU immigrants in Denmark have been stable. Residence length, presence of women, employment, hospitalization and criminal charges remain at similar levels across 2002-2013. In fact, the percentages of main drivers of social expenditure such as unemployment insurance and social assistance are lower in 2013 than in 2002. When distinguishing EU citizens by years of residence in Denmark, we see that EU citizens with shorter term residence, i.e. at most three years in Denmark, tend to be much younger, have fewer children, partake of a smaller percentage of key social benefits such as study grant, unemployment insurance and social assistance, and are less frequent users of the health care sector than EU citizens with longer term residence, i.e. more than three years in Denmark. We thus see that 'social integration', here conceptualized as the extent to which the welfare system is used, is weaker for EU citizens with shorter-term residence.

\section{Fiscal impact of EU citizens in Denmark between 2002 and 2013}

We computed the fiscal impact of EU citizens by directly ascribing individuals their public transfer and estimated cost for each public service and their contribution to each of the revenue sources in the dataset. This allows us to calculate for each year overall net fiscal impact of the $100 \%$ of population of EU citizens registered in Denmark. The fiscal impact is attained by calculating the difference in contributions and expenditures (for similar methods, see Dustmann and Frattini, 2014; Ruist, 2014). Below, Figure 2 presents the contribution, expenditure and net fiscal impact for the full EU population each year from 2002 to 2013, in aggregated and average figures. ${ }^{10}$ Our estimates show that over the entire period, immigrants from EU countries contribute with $€ 15,538 m$ to Danish welfare, expended $€ 8905 m$ in public income transfer and services and therefore made a positive fiscal contribution to Denmark of $€ 6633 \mathrm{~m}$. As shown in Figure 2a, the aggregated contribution and expenditure increase substantially over time, driven by the fast growth in EU 
immigration to Denmark. The figure also shows that the total fiscal contribution has grown almost every year, with the only exception being the period 2008-2010.

Figure $2 b$, which reports the average figures, demonstrates that the upward trend in net fiscal impact is driven by EU population growth. During the studied period, the average fiscal impact dropped somewhat when comparing 2002 with 2013. However, apart from the years of crisis, 2008-2010, it is also remarkable that the average fiscal impact remained rather constant around $€ 6000$ per EU citizen. The 2004, enlargement slightly reduced individual contribution. The average expenditure increased temporarily during the worst years of economic downturn, but individual expenditure returned to pre-crisis levels in 2012-2013. To sum up, the fiscal contribution of EU citizens in Denmark improves steadily over time, driven by a fast growing immigration population. EU citizens' extended access to Danish welfare, enlargements and the onset of one of the most severe economic crises in Europe have had a limited and temporary impact on individuals' reception of public income transfers and consumption of public services. 
(a) Total Fiscal Impact, in Million $€ 2013$

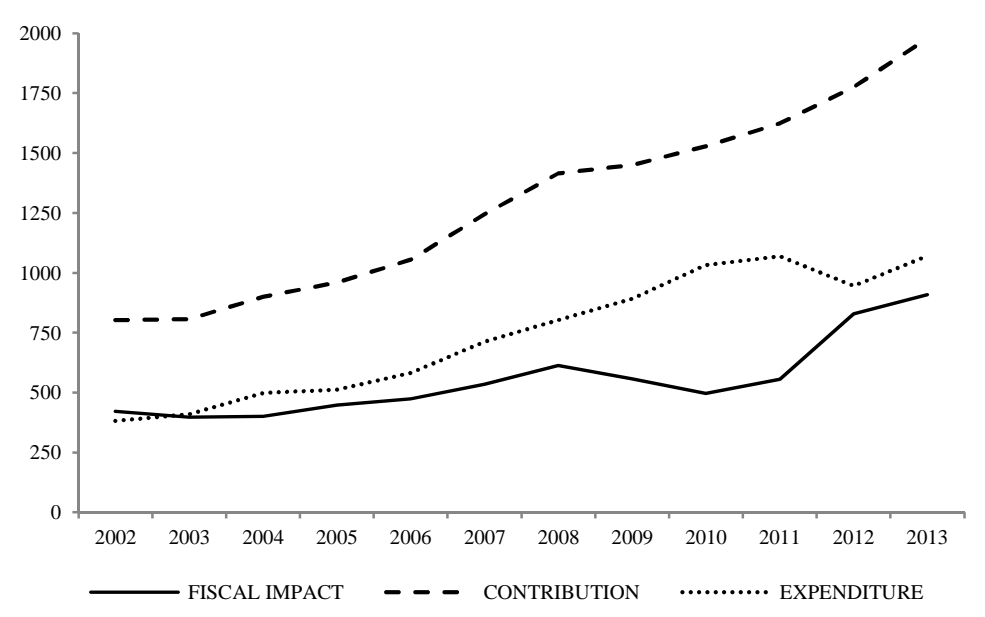

(b) Average Fiscal Impact, in €2013

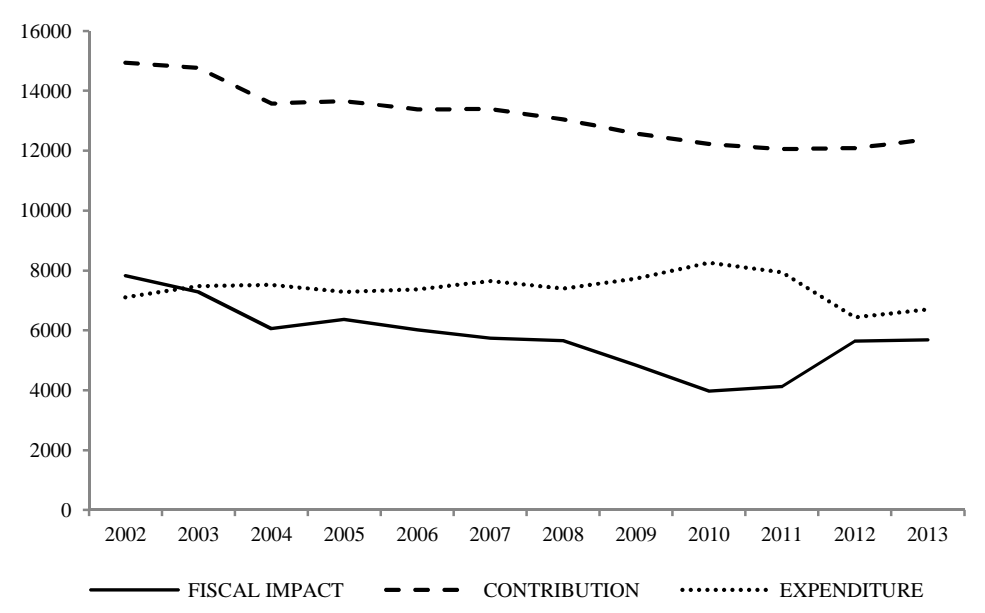

(c) Lower bound for Average Fiscal Impact, in €2013

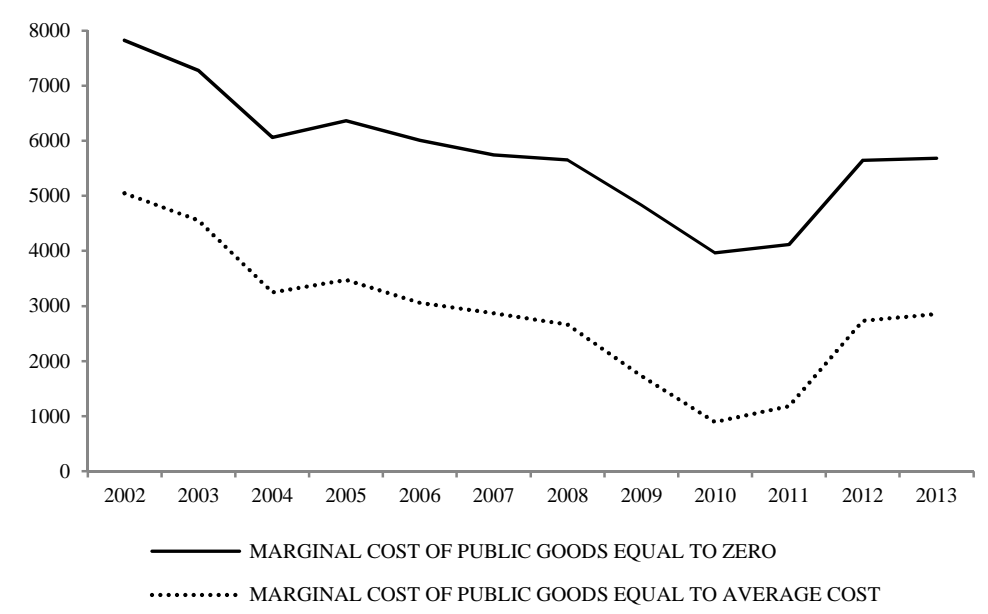

Figure 2. Fiscal impact of EU citizens in Denmark, 2002-2013 


\section{Fiscal impact by components: age, years since migration and country of origin}

As discussed previously, the evolution of EU immigration to Denmark clearly shows a fast increasing trend in the presence of EU citizens in the young worker age group. Not surprisingly, Figure 3a, which reports average fiscal impact by age group, shows that the net fiscal impact of EU immigrants is driven by the working age population of EU citizens. When we focus on children and youth groups, their average contribution is stable across the period, with children costing approximately $€ 5000$ to the Danish welfare state and the youth group (17-24) practically having no fiscal impact because of the presence of both students and workers in their first years on the labour market. A different picture arises for the group of retired EU citizens. In this case, their negative fiscal impact drops between 2007 and 2011 and returns to pre-2007 levels in 2012-2013. The differences in the fiscal impact across age groups show the importance of the age distribution of a population. EU citizens in Denmark are, however, overrepresented in the age groups, which makes a positive fiscal impact.

We now turn our focus to the different contributions of temporary, e.g. immigrants with residence under three years, and those with longer residence in Denmark, e.g. more than three years of residence. Figure 3 demonstrates that both groups of EU citizens have a positive contribution to Danish welfare. However, the contribution of EU citizens with shorter term residence in Denmark is on average $€ 4000$ lower than that of immigrants with more years in Denmark. Nevertheless, the consumption of public income and services of more recently arrived EU citizens is also much lower.

When comparing citizens from old versus new member states, Figure 3 shows that citizens from old member states contribute more but also benefit more, i.e. social expenditures are higher. The aggregated fiscal impact from the two groups of countries are positive for both throughout the examined period but, as also shown by Dustmann and Frattini (2014) and Ruist (2014), the net fiscal contribution is higher from EU citizens from old member states than from new member states. The fiscal impact from EU citizens from the new member states increases considerably from the EU10 enlargement in 2004 to 2008 and then drops from 2008 to 2010. From 2011 to 2013, we see a more modest increase again. The evolution is different for 
citizens from the old member states. We see a decrease in the net fiscal contribution until 2010, followed by an increase from 2011 to 2013.

(a) Fiscal Impact By Age

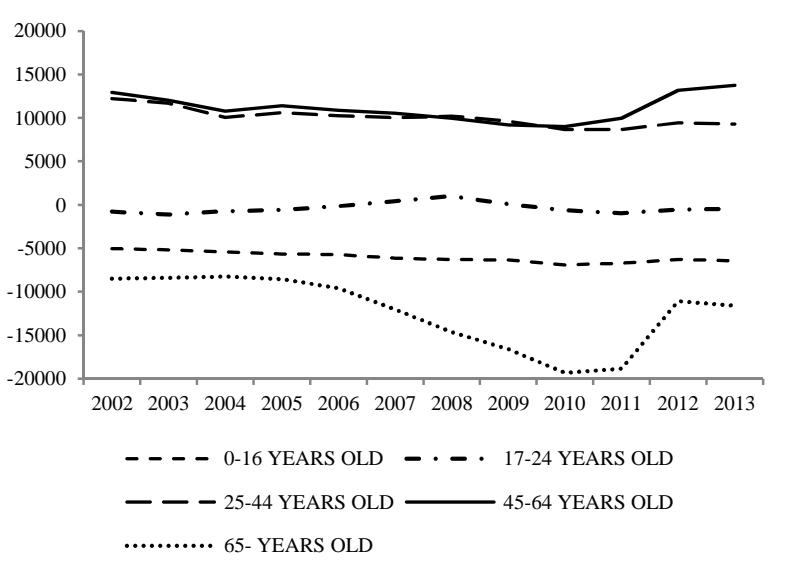

(b) Fiscal Impact By Years Since Migration

(c) Fiscal Impact Components By Years Since

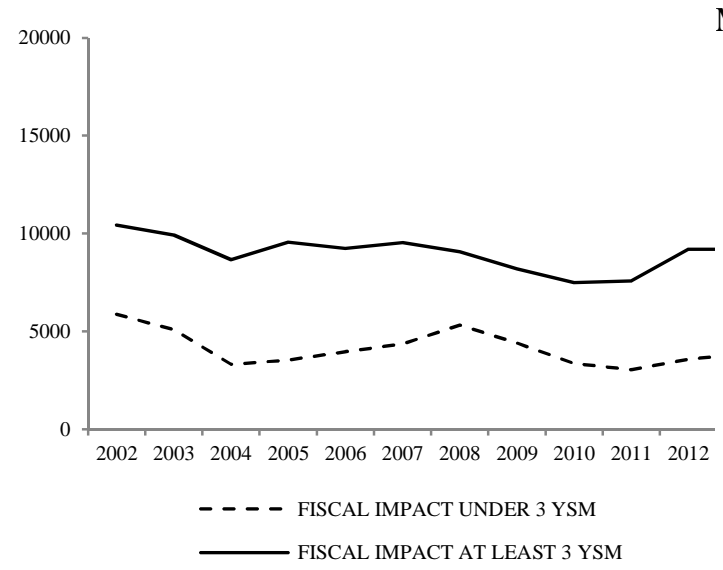

Migration

(d) Fiscal Impact By Country Of Origin (e) Fiscal Impact Components By Country Of

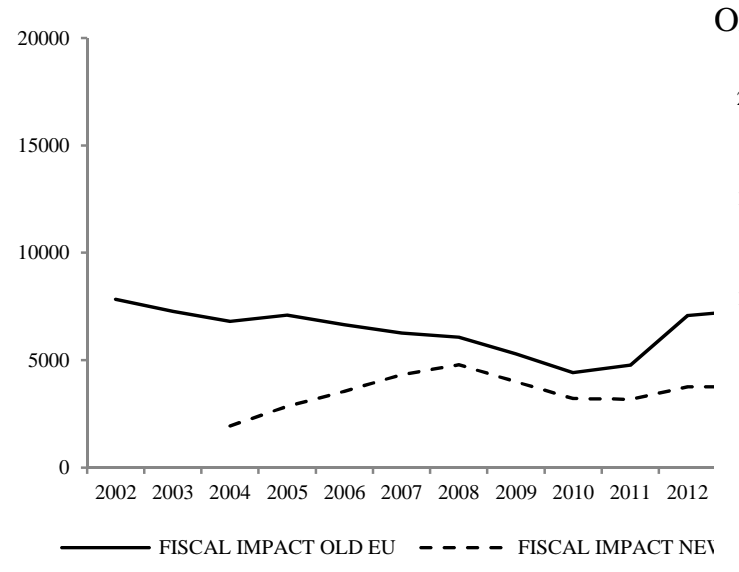

Origin

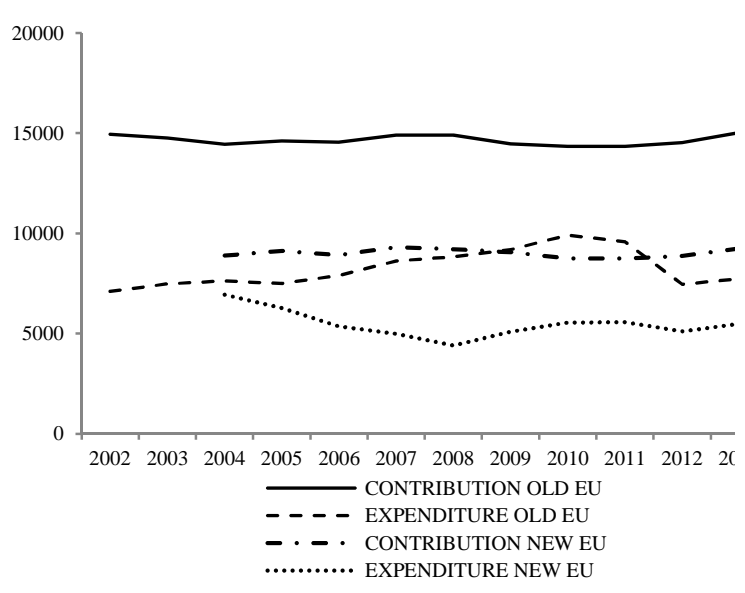


Figure 3. Average fiscal impact of EU citizens in Denmark in 2002-2013 by age, years since residence and country of origin, in $€ 2013$

\section{Conclusion}

The EU rules on free movement of people and the right to cross-border welfare are increasingly contested. The nexus between EU immigration and the welfare state became high politics in the UK referendum and has cast the EU into its worst crisis ever. The assumption that EU immigrants pose a net burden on the hosting welfare system has sounded loud and wide in recent years. The relationship between free movement rules and the welfare state is one of the most salient debates in current EU politics. The 'welfare burden' thesis has been the core of this debate. Its recurrent articulation calls for an empirical test, which has been the research endeavour of this paper.

In this article, we have examined the fiscal impact of EU immigration on the universalistic, tax-financed welfare state of Denmark. In the rather exceptional system of EU free movement for persons and cross-border welfare, Denmark constitutes a crucial case for examining whether EU immigrants are net burdens on a welfare state with the largest share of non-contributory social benefits, among other key characteristics.

The main contribution of this study has been an empirical inquiry into a solid claim with wide and growing political implications on the basis of a unique dataset, a long time span and for a $100 \%$ of the EU citizens residing in Denmark. The main conclusion is that even in this type of presumably exposed welfare state - and even during a time span of considerable structural changes - EU immigrants made a significant positive net contribution to the Danish welfare state. We thus reject the 'welfare burden' thesis for the universalistic, tax-financed welfare state of Denmark. Not only have EU citizens paid their way into the welfare system, but they have also made a considerable contribution to its fiscal sustainability through tax payment. The 'welfare burden' thesis disregards that inclusive, generous welfare states also oblige their residents to pay high taxes. Also disregarded is that EU rules permit member states to condition residence rights on EU immigrants not being an 'unreasonable burden' on the social assistance system of a host state. 
During the 12-year time span examined, the EU immigration pattern in Denmark changed substantively, but reliance on welfare remained rather stable. The number of EU citizens residing in Denmark increased by approximately 146\%, and the EU immigrant population came increasingly from the new member states and became more concentrated in the young worker age group. However, the average fiscal impact of EU citizens remained positive - even during the economic downturns of 2008-2010. Contributions decreased during the crisis years, and expenditures increased but stayed positive on a net balance, also when considering average cost of public goods. The differences in the fiscal impact across age groups showed the importance of the age distribution of a population. EU citizens in Denmark are, however, overrepresented in the age groups, which makes a positive fiscal impact. EU citizens with shorter term residence proved to contribute less but also to benefit less from the welfare state than those with longer term residence. Moreover, our study compared the fiscal impact of EU citizens from old member states with citizens from the new member states. The net contribution of citizens from new member states has been positive since the beginning of their Union membership, but lower than that of citizens from old member states. The latter group makes higher contributions because of higher earnings, but also benefits more from the welfare state than citizens from the new member states.

Our findings demonstrated that the universalistic, tax-based welfare budget of Denmark has benefitted considerably from EU immigration through a period of political and economic change. The findings did not support that this type of welfare state depends on a strong element of closure or is particularly unfit for a Union based on a logic of opening. We argue that because the Danish welfare state represents a crucial case, more likely to confirm the 'welfare burden' thesis than for example more residual or insurance-based welfare states, our findings have certain generalizability beyond Denmark. Having tested the 'welfare burden' thesis on a crucial case, we expect similar or higher positive fiscal impact for other welfare state types (George and Bennett, 2005, Gerring, 2007).

Our findings did not support the three key claims of the 'welfare burden' thesis. Between 2002 and 2013, EU free movement and cross-border welfare rules did not make a negative 
fiscal impact on the welfare state of Denmark. Instead, EU citizens made a significant positive contribution to the Danish welfare budget. Furthermore, EU immigrants from the new member states were positive contributors to the welfare budget throughout the examined period. EU immigrants from the new member states contributed less to the welfare budget than immigrants from the old member states, but they also benefitted less. Lastly, immigrants with short-term residence proved to contribute less to the welfare budget but also to benefit less. Also this group of EU citizens proved to pay their way into the Danish welfare state.

These findings strongly suggest that welfare states are more resilient to open borders than current political claims articulate. This should invite us to rethink the free movementwelfare state nexus. EU rules are rather exceptional, but not unconditional. They offer no open invitation into the welfare state. The average profile of EU immigrants in Denmark departs remarkably from what is coined in concepts of 'welfare tourism', 'welfare migration' or 'welfare burdens'. Instead, EU immigrants in Denmark are relatively young, tend not to stay over the long term and contribute financially to the maintenance of the welfare state.

\section{Acknowledgements}

We would like to thank Rob Cornelissen, Jacob Gerner Hariri, Frederik Hjorth, Torben Tranæs, Herwig Verschueren and the three anonymous referees for their extensive comments on previous versions of this article. Special thanks goes to Anders Woller Nielsen for research assistance.

\section{Funding}

The research for this article is part of the TransJudFare project, funded by the Norface Welfare State Futures program.

\section{Notes}

1. In May 2004, eight Central and Eastern European States became members of the European Union: Czech Republic, Estonia, Hungary, Latvia, Lithuania, Poland, 
Slovakia and Slovenia, hereafter termed as EU8. Also, Malta and Cyprus became EU members in 2004.

2. The recent studies by the economists Dustmann, Frattini and Hall and Ruist are the seminal exceptions here. UK studies based on survey information from the national Labour Force Survey have demonstrated positive fiscal consequences of different samples of EU immigrants in the UK. Dustmann, Frattini and Halls show that immigrants from EU8 countries that joined the European Union in 2004 had a higher net fiscal impact than similar UK citizens (Dustmann et al., 2010). EU8 immigrants made higher direct and indirect tax contribution, and they claimed less public benefits and services than similar UK citizens. In their 2014 paper, Dustmann and Frattini considered the fiscal impact of two different populations: the population of migrants from the European Economic Area (EEA) in the UK between 1995 and 2011 and the immigrants from EU10 countries, i.e., EU8 plus Bulgaria and Romania, and rest of EU countries over the period between 2001 and 2011 (Dustmann and Frattini, 2014). Dustmann and Frattini found that EEA migrants contributed 10\% more than UK citizens and that immigrants arriving in the 2000s also made a positive fiscal contribution, irrespective of their country of origin. Moreover, a Swedish study based on administrative data of approximately 4300 immigrants from old EU countries and 3000 immigrants from EU10 countries in Sweden found that compared to Swedish citizens, migrants from old EU countries had a larger contribution, and migrants from new EU countries had a similar contribution (Ruist, 2014). The EU10 countries investigated by Ruist are EU8 countries plus Malta and Cyprus.

3. See Eurostat data for social protection statistics on financing concerning social protection receipts by type: $\underline{\text { http://ec.europa.eu/eurostat/statistics- }}$ explained/index.php/Social_protection_statistics_financing\#Social_protection_receipts_by type

4. However, the rights of frontier workers depart from the general rule of nonexportability, as workers residing in one member state and working in another have a right to export their social advantages.

5. Ruist (2014) estimates the net fiscal impact of EU citizens in Sweden in 2007 with at most 4 years of residence. Jacobsen, Junge and Skaksen (2011) consider for the 
same purpose a sample of higher educated immigrants in Denmark in 2009 with at most 7 years of residence.

6. For Danish authorities' standard estimation of contribution via VAT and levies, see section 6.1.3.1 of the Danish tax authorities methods for the calculation of tax revenues (2013) http://www.skm.dk/media/138783/provenu_og_metode.pdf.

7. The online appendix 'Estimations of welfare service costs in Denmark, 20022013. A note on data collection' further details the procedures for the estimations. Table 1 in the appendix sets out the final estimations used for each services between 2002 and 2013.

8. Data on yearly costs of providing public goods are extracted from Statistics Denmark, at http://www.statistikbanken.dk/statbank5a/SelectVarVal/Define.asp?MainTable=OFF 24\&PLanguage $=0 \&$ PXSId=0\&wsid=cfsearch ( ID: 'OFF24'). Items of expenditure include rows one through five (i.e., 'General Public Services', 'Defense', 'Public Order and Security', 'Economic Affairs' and 'Environmental Protection'). Data on the population size are extracted from Statistics Denmark at http://www.statistikbanken.dk/statbank5a/SelectVarVal/Define.asp?MainTable=HIS $\underline{B} 3 \&$ PLanguage $=0 \&$ PXSId=0 $(I D:$ 'HISB3'). The unit cost of yearly public goods provision is calculated by dividing the total costs of public goods provision in the given year with the total population size in the same year.

9. The Online appendix presents the age distribution of EU citizens during the last 5 years of our sample, disaggregated by country of origin. As in the Swedish case (Ruist, 2014), immigrants from new EU countries are more concentrated in the younger working age group than immigrants from old EU countries, and both groups are much more heavily concentrated for the EU population than the population with Danish citizenship.

${ }^{10}$ The Online appendix reports the amount per year in $€ 2013$ for the full EU population and for the different groups considered in this article. 


\section{References}

Chaloff J and Lemaitre G (2009) Managing Highly-Skilled Labour Migration - A Comparative Analysis of Migration Policies and Challenges in OECD Countries . OECD Social, Employment and Migration Working Papers (79) OECD Publishing, Paris

Christensen A and Malmstedt M (2000) Lex Loci Laboris versus Lex Loci Domicilii - An Inquiry into the Normative Foundations of European Social Security Law. European Journal of Social Security 2(1): 69-111.

Cornelissen R (1996) The Principle of Territoriality and the Community Regulations on Social Security (Regulations 1408/71 and 574/72). Common Market Law Review 33(3): 439-71.

Cox R (2004) The Path $\llbracket$ Dependency of an Idea: Why Scandinavian Welfare States Remain Distinct. Social Policy \& Administration 38(2): 204-19.

Dougan M (2013) The Bubble that Burst: Exploring the Legitimacy of the Case Law on the Free Movement of Union Citizens. In: Adams M, de Waele H, Meeusen J, and Straetmans G (eds). Judging Europes's Judges. The Legitimacy of the Case Law of the European Court of Justice. Hart Publishing: Oxford, pp.127-154.

Dustmann C and Frattini T (2014) The Fiscal Effects of Immigration to the UK. The Economic Journal 124(580): 593-643.

Dustmann C, Frattini T and Halls C (2010) Assessing the Fiscal Costs and Benefits of A8 Migration to the UK. Fiscal Studies 31(1): 1-41.

Esping-Andersen G (1990) The Three Worlds of Welfare Capitalism. Princeton: Princeton University Press.

Ferrera M (2005) The Boundaries of Welfare: European Integration and the New Spatial Politics of Social Protection. Oxford: Oxford University Press.

Geddes A and Hadj-Abdou L (2016) An unstable equilibrium: freedom of movement and the welfare state in the European Union. In: Freeman GP and Mirilovic N (eds) Handbook on Migration and Social Policy. Cheltenham: Edward Elgar Publishing Limited, pp. 222-238. 
George AL and Bennett A (2005) Case studies and theory development in the social sciences. The MIT Press.

Gerring J (2007) Is there a (viable) crucial-case method? Comparative Political Studies 40(3): 231-53.

Heindlmaier A and Blauberger M (2017) Enter at your own risk: free movement of EU citizens in practice. West European Politics. E-publication first.

Hemerijck A (2013) Changing Welfare States. Oxford: Oxford University Press.

Hjorth F (2016) Who benefits? Welfare Chauvinism and National Stereotypes. European Union Politics 17(1): 3-24.

Höpner M and Schäfer A (2012) Embeddedness and Regional Integration: Waiting for Polanyi in a Hayekian Setting. International Organization 66(03): 429-55.

Jacobsen RH, Junge M and Skaksen JR (2011) Højtuddannede indvandreres bidrag til det danske samfund. Working Paper. Available at: openarchive.cbs.dk (accessed 29 May 2017).

Kvist J (2004) Does EU enlargement start a race to the bottom? Strategic interaction among EU member states in social policy. Journal of European Social Policy 14(3): 301-18.

Lindbom A (2001) Dismantling the Social Democratic welfare model? Has the Swedish Welfare State Lost Its Defining Characteristics?. Scandinavian Political Studies 24(3): 171-93.

Martinsen DS (2005) The Europeanization of Welfare 『 The Domestic Impact of Intra|European Social Security. Journal of Common Market Studies 43(5): 1027-54.

Martinsen DS and Vollaard H (2014) Implementing Social Europe in Times of Crises: Re-established Boundaries of Welfare? West European Politics 37(4): 677-92.

Reenen JV (2016) The Aftermath of the Brexit Vote - The Verdict From a Derided Expert, The LSE Politics and Policy blog on 2 August 2016. Available at http://blogs.lse.ac.uk/politicsandpolicy/the-aftermath-of-the-brexit-vote-averdict-from-those-of-those-experts-were-not-supposed-to-listen-to/ (accessed 29 May 2017). 
Ruhs M (2013) The Price of Rights: Regulating International Labor Migration. Princeton: Princeton University Press.

Ruhs M (2015) Is Unrestricted Immigration Compatible with Inclusive Welfare States? The (Un) Sustainability of EU Exceptionalism. Oxford University Working Paper, 125: 1-46.

Ruist J (2014) Free Immigration and Welfare Access: The Swedish Experience. Fiscal Studies 35(1): 19-39.

Scharpf FW (2002) The European Social Model: Coping with the Challenges of Diversity. Journal of Common Market Studies 40(4): 645-70.

Scharpf FW (2010) The Asymmetry of European Integration, or Why the EU Cannot Be a 'Social Market Economy'. Socio-Economic Review 8(2): 21150 .

Van der Mei AP (2003) Free Movement of Persons Within the European Community. Cross-Border Access to Public Benefits. Oxford - Portland Oregon: Hart Publishing. 